Article

\title{
Dietary Selenium Intake and Subclinical Hypothyroidism: A Cross-Sectional Analysis of the ELSA-Brasil Study
}

\author{
Gustavo R. G. Andrade ${ }^{1}\left(\mathbb{D}\right.$, Bartira Gorgulho ${ }^{2} \mathbb{( D}^{(}$, Paulo A. Lotufo $^{3}$, Isabela M. Bensenor ${ }^{3}$ (D) and \\ Dirce M. Marchioni ${ }^{1, * \text { (i) }}$ \\ 1 Department of Nutrition, School of Public Health, University of São Paulo, São Paulo CEP 03178-200, Brazil; \\ gustavoandrade@usp.br \\ 2 Department of Food and Nutrition, School of Nutrition, Federal University of Mato Grosso, \\ Cuiabá CEP 78060-900, Brazil; bartira.gorgulho@gmail.com \\ 3 Clinical and Epidemiological Research Center, University Hospital, University of São Paulo, \\ São Paulo CEP 05508-000, Brazil; palotufo@usp.br (P.A.L.); isabensenor@gmail.com (I.M.B.) \\ * Correspondence: marchioni@usp.br; Tel.: +55-11-3061-7856
}

Received: 3 May 2018; Accepted: 28 May 2018; Published: 30 May 2018

check for updates

\begin{abstract}
Selenium (Se) participates in several enzymatic reactions necessary for regulating the homeostasis of thyroid hormones. We aimed to analyze the association between dietary Se intake and subclinical hypothyroidism. Baseline data from the Longitudinal Study of Adult Health (Estudo Longitudinal de Saúde do Adulto-ELSA-Brasil) in Brazil were analyzed, with a final sample size of 14,283 employees of both sexes aged 35-74 years. Dietary data was collected using a previously validated food frequency questionnaire. Subclinical hypothyroidism was categorized as thyroid-stimulating hormone levels of $>4.0 \mathrm{IU} / \mathrm{mL}$ and free prohormone thyroxine levels within normal limits, without administering drugs for thyroid disease. A multiple logistic regression model was used to assess the relationship between the presence of subclinical hypothyroidism and tertiles of Se consumption. The prevalence of subclinical hypothyroidism in the study sample was $5.4 \%$ (95\% confidence interval [CI], 3.8-7.0\%). Compared with the first tertile of Se intake, the second (odds ratio [OR], 0.79; 95\% CI, 0.65-0.96\%) and third (OR, 0.72; 95\% CI, 0.58-0.90\%) tertiles were inversely associated with subclinical hypothyroidism, however further research is needed to confirm the involvement of Se in subclinical hypothyroidism using more accurate methodologies of dietary assessment and nutritional status to evaluate this relationship.
\end{abstract}

Keywords: selenium; diet; subclinical hypothyroidism; adults; thyroid

\section{Introduction}

One of the diseases that affect the thyroid gland is subclinical hypothyroidism, which is characterized by elevated serum levels of thyroid-stimulating hormone (TSH) at a concentration recommended for prohormone thyroxine (T4) and active hormone triiodothyronine (T3). The decompensated levels of thyroid hormones may contribute to atherosclerotic events [1] and an increase in cardiovascular-related mortality [2]. Also, observational longitudinal studies have shown an inverse association between selenium exposure and risk of some cancer types but still to be confirmed [3]. It is estimated that subclinical hypothyroidism affects $3-8 \%$ of the general population and is more common in women than in men [4]. In Brazil, an epidemiological study in elderly reported that prevalence of subclinical hypothyroidism was 6.5\% [5]. Olmos et al. [6], in the Brazilian Longitudinal Study of Adult Health (ELSA-Brasil), reported that subclinical hypothyroidism prevalence was $5.4 \%$ overall. 
Hypothyroidism is sometimes difficult to diagnosis, since most of the symptoms, such as fatigue, lack of concentration, dry skin, are nonspecific and frequently attributed to other causes or to the aging process itself [2]. Studies conducted in Brazil demonstrated the influence of race on the prevalence of hypothyroidism, which was lower in black and brown people [6,7]. Also, gender, race and socioeconomic status were reported to influence the diagnosis and treatment of hypothyroidism, with men, browns, blacks and subjects with low socioeconomic status having lower frequencies of treatment for hypothyroidism [6].

The thyroid gland contains high levels of selenium (Se) [8] and expresses a variety of selenoproteins that are involved in protection of oxidative stress and metabolism of thyroid hormones (TH) [9-11]. Se deficiency impairs regular synthesis of selenoproteins and adequate TH metabolism. However, on selenium deficient diets, endocrine organs and the brain are preferentially supplied [12], especially the thyroid gland, that retains the trace element very efficiently $[11,13]$. On the other hand, Parshukova et al. [14], studying the interrelationships between seasonal selenium levels and levels of thyroid gland hormones over a year, verified that low levels of plasma selenium affected thyroid hormone levels in humans living in North European Russia. Wu et al. [15] reported in a study on China that higher serum selenium was associated with lower chance to present subclinical hypothyroidism.

Se nutritional status varies worldwide because the Se content in food is related to the amount in the soil [16]. Thus, the plasma Se concentrations are variable in different populations around the world. For instance, plasma Se is higher in the USA compared to the South Islands of New Zealand [17]. A study in São Paulo, Brazil, using biomarkers of Se status, reported that plasma Se concentrations were very low compared with those observed in other healthy populations, such as the USA, New Zealand and UK [18]. They hypothesized that, as Se intake can be predicted by plasma Se concentrations, this lower concentration could be a consequence of low Se intake and the low Se content in foods in this southern region of Brazil. According to a study conducted by Favaro et al. [19], the food intake of selenium in Brazil can vary from 20 to $114 \mu \mathrm{g} /$ day, that is, from low to adequate, depending on the region that was studied and the socioeconomic level of the population. Usually the main sources of Se are cereals, meats and fish [20]. Ferreira et al. [21], evaluated the selenium content in foods consumed in different states of Brazil and the ingredients that are considered staple food, such as beans, wheat flour, rice, cassava flour and maize, were poor sources of selenium, while animal sources, more expensive, were better sources.

Despite the expected relationship between Se and thyroid function, only one [22] of several studies [22-26], which evaluated thyroid metabolism in different populations, found a positive effect of Se supplementation on thyroid hormone levels.

The objective of this study was to analyze the association between the dietary intake of Se and subclinical hypothyroidism based on baseline data from the Longitudinal Study of Adult Health (Estudo Longitudinal de Saúde do Adulto-ELSA-Brasil).

\section{Materials and Methods}

This cross-sectional study analyzed baseline data from the ELSA study in Brazil, a multicenter cohort study focused on chronic diseases, particularly cardiovascular diseases and comprised 15,105 employees from six Brazilian institutions of higher education and research aged 35-74 years.

Baseline data were collected from 2008 to 2010 by conducting interviews to identify sociodemographic, lifestyle, anthropometric, dietary and clinical characteristics. Details of the study design were reported by Aquino et al. [27] and Bensenor et al. [28].

The study sample consisted of 14,283 participants. The exclusion criteria were the use of drugs that modified thyroid function, lack of information on TSH and T4, absence of a food frequency questionnaire (FFQ) and energy intake lower than the first percentile or higher than the 99th percentile of the distribution (Figure 1). 


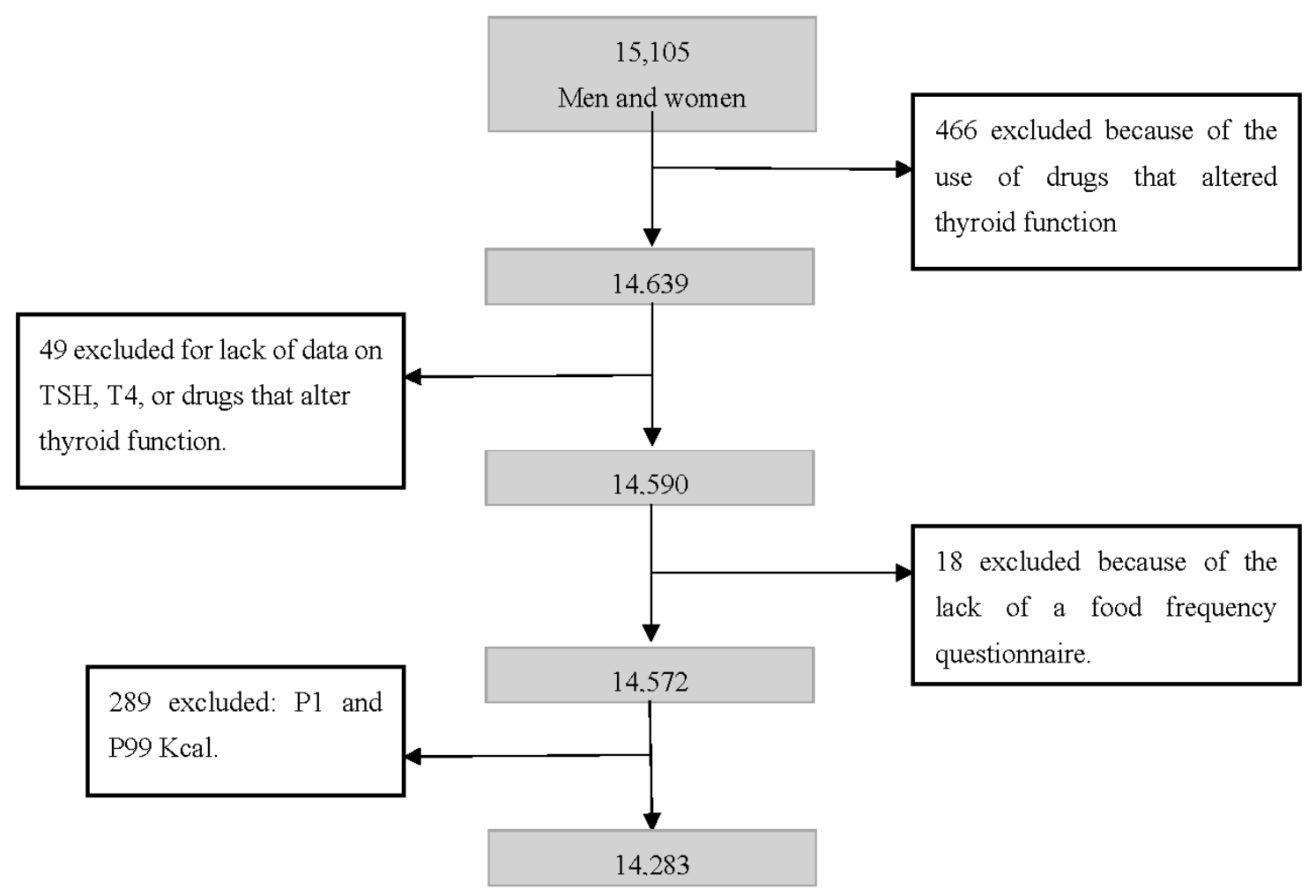

Figure 1. Exclusion criteria and final sample. ELSA-Brasil, Brazil 2017.

\subsection{Ethical Aspects}

The ELSA-Brasil protocol was approved at all 6 centers: Oswaldo Cruz Foundation (Fiocruz), Federal University of Bahia (UFBA), Federal University of Espírito Santo (UFES), Federal University of Minas Gerais (UFMG), Federal University of Rio Grande do Sul (UFRGS) and University of São Paulo (USP), by the institutional review boards addressing research in human participants. All participants signed a written informed consent form.

\subsection{Diet}

Food intake was obtained using a validated FFQ with 114 food items to evaluate diet in the past 12 months [29], covering three sections: food products/food preparations, measures of consumed products and consumption frequencies with eight response options: "more than 3 times a day", "2 to 3 times a day", "once a day", " 5 to 6 times a week", "2 to 4 times a week", "once a week", "1 to 3 times a month" and "never/rarely". The measures of consumed foods were determined using a toolkit [30].

\subsection{Subclinical Hypothyroidism}

Venous blood was withdrawn from the ELSA participants after a 12-h fast and dosing of TSH. The levels of free T4 were analyzed in participants with low TSH $(<0.4 \mathrm{IU} / \mathrm{mL})$ or high TSH (>4.0 IU/mL). TSH and FT4 were measured using a third-generation immunoenzymatic assay (Siemens, Deerfield, IL, USA) in serum obtained from centrifuged venous blood samples after overnight fasting [31]. FT4 levels were measured in participants exhibiting altered TSH levels. In this study, reference range levels were $0.4-4.0 \mathrm{mIU} / \mathrm{L}$ for TSH and 10.3-24.45 pmol/L for FT4. We excluded participants using drugs that could interfere with thyroid function: amiodarone, carbamazepine, carbidopa, phenytoin, furosemide, haloperidol, heparin, interferon, levodopa, lithium, metoclopramide, propranolol, primidone, rifampicin and valproic acid.

ELSA-Brasil study participants were classified into five categories of thyroid function, according to TSH and FT4 levels and information related to the use of medication to treat thyroid disorders: clinical 
hyperthyroidism (low serum TSH and high FT4 levels or use of medication to treat hyperthyroidism), subclinical hyperthyroidism (low serum TSH, normal FT4 levels and no use of drugs to treat thyroid diseases), euthyroidism (normal TSH and no use of thyroid drugs), subclinical hypothyroidism (high TSH levels, normal FT4 levels and no use of drugs to treat thyroid diseases) and clinical hypothyroidism (high TSH and low FT4 levels, or use of levothyroxine to treat hypothyroidism). For the descriptive analysis all types were included, but, only participants with subclinical hypothyroidism or euthyroidism were included on the regression models.

The cutoff points used to determine subclinical hypothyroidism were TSH levels of $>4.0 \mathrm{IU} / \mathrm{mL}$ with free T4 within the recommended doses, without the use of drugs that alter thyroid function.

\subsection{Statistical Analysis}

Multiple logistic regression models with nutrients adjusted for total energy, using the residuals method [32], were conducted in the sample that included only participants with subclinical hypothyroidism or euthyroidism. The models were adjusted for age (35-59 years, $\geq 60$ years), sex (male and female), nutritional status (body mass index) in $\mathrm{kg} / \mathrm{m}^{2}$ (low weight, eutrophic, overweight and obese according to the cut-off points recommended by the World Health Organization) [33], smoking (no for ex-smokers and non-smokers and yes for smokers), hypertension (yes or no; obtained from systolic blood pressure $\geq 140 \mathrm{mmHg}$ and/or diastolic blood pressure $\geq 90 \mathrm{mmHg}$, or use of drugs for treating hypertension), diabetes (yes or no, obtained from data on post-prandial glycaemia, glycated hemoglobin, use of medications for treating diabetes and previous diagnosis of diabetes), dyslipidemia (yes or no, obtained from previous diagnosis of the disease and use of medicines), per capita income (obtained from data on the net family income of the past month, by the average of extreme values of each category and number of family members who depended on this income to live), current alcohol use (yes or no), level of physical activity during leisure (low, moderate, or high) according to the International Physical Activity Questionnaire (IPAQ), change in diet (yes or no) and use of dietary supplements (regularly or not).

Micronutrients that correlated with the outcome of interest and thyroid function, including zinc, vitamin A, iodine and sodium, were also used as adjustment variables [34]. Urinary sodium (g/day) was used as a proxy for iodine consumption [35].

All analyses were performed using Stata Statistical Software (release 14, 2015, StataCorp LP, College Station, TX, USA) and the level of significance was set at 5\%.

\section{Results}

The total sample had a higher proportion of participants who were Caucasian, female, aged 35-59 years, with per capita income in the first tertile, non-smokers, alcohol users, with low physical activity level during leisure, without significant changes in diet, overweight, non-hypertensive, non-diabetic, dyslipidemic and euthyroid (Table 1).

The major food sources of dietary selenium verified in this study were: rice $(23 \%)$, meat $(13 \%)$, bread $(12 \%)$, beans $(10 \%)$, milk $(10 \%)$, fish $(8 \%)$, pasta $(5 \%)$ and nuts $(4 \%)$.

The lower tertile of Se consumption had a higher proportion of participants who were males, of Black and mixed race, aged 35-59 years, in the lowest tertile of per capita income, non-smokers, alcohol consumers, with a low level of physical activity during leisure, without significant changes in diet, not using dietary supplements, overweight, non-hypertensive, non-diabetic, dyslipidemic and euthyroid. The highest tertile of Se intake had a predominance of participants who were Caucasian, female, aged 39-59 years, in the highest tertile of per capita income, non-smokers, alcohol users, with a low level of physical activity during leisure, without significant changes in the diet, not using food supplements, non-hypertensive, non-diabetic, dyslipidemic and euthyroid (Table 1).

The analysis of the other nutrients showed a correlation with thyroid function with respect to the consumption tertiles relative to Se intake tertiles (Table 2). All analyzed micronutrients were positively 
correlated with Se intake, particularly total fats, which presented a higher correlation coefficient $(\mathrm{r}=0.33)($ Table 2$)$.

Table 1. Description of the total population and selenium consumption per tertile in the ELSA-Brasil study, 2017.

\begin{tabular}{|c|c|c|c|c|c|c|c|c|c|}
\hline & \multirow{2}{*}{\multicolumn{2}{|c|}{ Total }} & \multicolumn{7}{|c|}{ Selenium Intake * } \\
\hline & & & \multicolumn{2}{|c|}{$\begin{array}{l}\text { First Tertile } \\
(0-187 \mathrm{mg})\end{array}$} & \multicolumn{2}{|c|}{$\begin{array}{l}\text { Second Tertile } \\
(188-232 \mathrm{mg})\end{array}$} & \multicolumn{2}{|c|}{$\begin{array}{l}\text { Third Tertile } \\
(233-1087 \mathrm{mg})\end{array}$} & \multirow[t]{2}{*}{$p$ Value $* *$} \\
\hline & $\mathbf{N}$ & $\%$ & $\mathbf{N}$ & $\%$ & $\mathbf{N}$ & $\%$ & $\mathbf{N}$ & $\%$ & \\
\hline Sex & & & & & & & & & $<0.001$ \\
\hline Male & 6518 & 45.6 & 2519 & 53.0 & 1979 & 41.6 & 2020 & 42.4 & \\
\hline Female & 7765 & 54.4 & 2242 & 47.0 & 2782 & 58.4 & 2741 & 57.6 & \\
\hline Self-declared race & & & & & & & & & $<0.001$ \\
\hline Caucasian & 7418 & 52.5 & 2045 & 43.4 & 2540 & 53.9 & 2833 & 60.3 & \\
\hline Black and Mixed & 6204 & 43.9 & 203 & 53.1 & 190 & 42.3 & 111 & 36.4 & \\
\hline Others & 497 & 3.6 & 161 & 3.5 & 179 & 3.8 & 157 & 3.3 & \\
\hline Age & & & & & & & & & $<0.001$ \\
\hline $35-59$ years & 11,271 & 78.9 & 3892 & 80.5 & 3831 & 80.5 & 3548 & 74.5 & \\
\hline$\geq 60$ years & 3012 & 21.1 & 869 & 18.6 & 930 & 19.5 & 1213 & 25.5 & \\
\hline Per capita income & & & & & & & & & $<0.001$ \\
\hline First tertile (USD 14.85-520.51) & 5175 & 36.1 & 2498 & 52.7 & 1665 & 35.1 & 1012 & 21.3 & \\
\hline Second tertile (USD 529.87-1059.74) & 4992 & 34.9 & 1476 & 31.1 & 1739 & 36.6 & 1707 & 36.0 & \\
\hline Third tertile (USD 1115.32-4238.97) & 4135 & 29.0 & 768 & 16.2 & 1342 & 28.3 & 2025 & 42.7 & \\
\hline Current smoking & & & & & & & & & $<0.001$ \\
\hline No & 12,446 & 87.1 & 3979 & 83.6 & 4182 & 87.9 & 4285 & 90.0 & \\
\hline Yes & 1836 & 12.9 & 782 & 16.4 & 578 & 12.1 & 476 & 10.0 & \\
\hline Current alcohol use & & & & & & & & & $<0.001$ \\
\hline No & 4302 & 30.1 & 1675 & 35.2 & 1434 & 30.1 & 1193 & 25.1 & \\
\hline Yes & 9978 & 69.9 & 3085 & 64.8 & 3325 & 69.9 & 3568 & 74.9 & \\
\hline Physical activity during leisure & & & & & & & & & $<0.001$ \\
\hline Low & 10,796 & 76.7 & 3865 & 82.6 & 3621 & 77.3 & 3310 & 70.3 & \\
\hline Moderate & 1986 & 14.1 & 499 & 10.7 & 683 & 14.6 & 804 & 17.2 & \\
\hline Vigorous & 1287 & 9.2 & 315 & 6.7 & 379 & 8.1 & 593 & 12.5 & \\
\hline Change in diet & & & & & & & & & $<0.001$ \\
\hline No & 9903 & 69.4 & 3517 & 73.9 & 3247 & 68.3 & 3139 & 66.0 & \\
\hline Yes & 4366 & 30.6 & 1243 & 26.1 & 1507 & 31.7 & 1616 & 34.0 & \\
\hline Use of dietary supplements & & & & & & & & & $<0.001$ \\
\hline No & 10,887 & 77.3 & 3940 & 84.2 & 3639 & 77.5 & 3308 & 70.5 & \\
\hline Regularly & 1823 & 12.9 & 391 & 8.3 & 579 & 12.3 & 853 & 18.0 & \\
\hline Not regularly & 1381 & 9.8 & 353 & 7.5 & 480 & 10.2 & 548 & 11.5 & \\
\hline Nutritional status & & & & & & & & & $<0.001$ \\
\hline Low weight & 129 & 0.9 & 57 & 1.2 & 34 & 0.7 & 38 & 0.8 & \\
\hline Eutrophic & 5175 & 36.2 & 1672 & 35.1 & 1662 & 34.9 & 1841 & 38.7 & \\
\hline Overweight & 5740 & 40.2 & 1898 & 39.9 & 1940 & 40.8 & 1902 & 40.0 & \\
\hline Obese & 3234 & 22.7 & 1,32 & 23.8 & 1124 & 23.6 & 978 & 20.5 & \\
\hline Hypertension & & & & & & & & & $<0.001$ \\
\hline No & 9930 & 69.5 & 3047 & 64.0 & 3120 & 65.5 & 3163 & 66.4 & \\
\hline Yes & 4951 & 34.7 & 1714 & 36.0 & 1640 & 34.5 & 1597 & 33.6 & \\
\hline Diabetes & & & & & & & & & $<0.001$ \\
\hline No & 11,558 & 80.9 & 3797 & 79.8 & 3886 & 81.6 & 3875 & 81.4 & \\
\hline Yes & 2724 & 19.1 & 963 & 20.2 & 875 & 18.4 & 886 & 18.6 & \\
\hline Dyslipidemia & & & & & & & & & $<0.001$ \\
\hline No & 6007 & 42.4 & 2225 & 47.0 & 1926 & 40.8 & 1856 & 39.4 & \\
\hline Yes & 8169 & 57.6 & 2510 & 53.0 & 2799 & 59.2 & 2860 & 60.6 & \\
\hline Thyroid function & & & & & & & & & $<0.001$ \\
\hline Subclinical hypothyroidism & 770 & 5.4 & 276 & 5.8 & 252 & 5.3 & 242 & 5.1 & \\
\hline Clinical hypothyroidism & 1061 & 7.4 & 256 & 5.4 & 383 & 8.0 & 422 & 8.9 & \\
\hline Euthyroid & 12,171 & 85.3 & 4146 & 87.1 & 4022 & 84.5 & 4003 & 84.1 & \\
\hline Subclinical hyperthyroidism & 186 & 1.3 & 57 & 1.2 & 70 & 1.5 & 59 & 1.2 & \\
\hline Clinical hyperthyroidism & 95 & 0.6 & 26 & 0.5 & 34 & 0.7 & 35 & 0.7 & \\
\hline
\end{tabular}

* Energy-adjusted nutrient; ${ }^{* *} p$ values of the chi-square test. 
Table 2. Intake of energy and micronutrients and urinary sodium per selenium intake tertile in the ELSA-Brasil study, 2017.

\begin{tabular}{|c|c|c|c|c|c|c|c|c|c|}
\hline & \multirow{3}{*}{$\begin{array}{c}\text { Total } \\
\mathbf{N}\end{array}$} & \multicolumn{7}{|c|}{ Selenium Intake * } & \multirow{3}{*}{$\mathbf{R}^{* * *}$} \\
\hline & & \multicolumn{2}{|c|}{$\begin{array}{c}\text { First Tertile } \\
(0-187 \mathrm{mg})\end{array}$} & \multicolumn{2}{|c|}{$\begin{array}{l}\text { Second Tertile } \\
\text { (188-232 mg) }\end{array}$} & \multicolumn{2}{|c|}{$\begin{array}{l}\text { Third Tertile } \\
(233-1087 \mathrm{mg})\end{array}$} & \multirow[t]{2}{*}{$p$ Value $* *$} & \\
\hline & & $\mathbf{N}$ & $\%$ & $\mathbf{N}$ & $\%$ & $\mathbf{N}$ & $\%$ & & \\
\hline Energy (average) & & & & & & & & $<0.001$ & _- \\
\hline First tertile (1900 kcal) & 4761 & 1049 & 22.0 & 2202 & 46.2 & 1510 & 31.7 & & \\
\hline Second tertile (2735 kcal) & 4761 & 1599 & 33.6 & 1529 & 32.1 & 1633 & 34.3 & & \\
\hline Third tertile $(4166 \mathrm{kcal})$ & 4761 & 2113 & 44.4 & 1030 & 21.6 & 1618 & 34.0 & & \\
\hline Zinc $^{*}$ (average) & & & & & & & & $<0.001$ & 0.16 \\
\hline First tertile (13 mg) & 4761 & 2562 & 53.8 & 1226 & 25.7 & 973 & 20.4 & & \\
\hline Second tertile (16 mg) & 4761 & 1278 & 26.8 & 1833 & 38.5 & 1650 & 34.7 & & \\
\hline Third tertile (21 mg) & 4761 & 921 & 19.3 & 1702 & 35.8 & 2138 & 44.9 & & \\
\hline Vitamin $A^{*}$ (average) & & & & & & & & $<0.001$ & 0.11 \\
\hline First tertile (71 mg) & 4761 & 1887 & 39.6 & 1614 & 33.9 & 1260 & 26.5 & & \\
\hline Second tertile (125 mg) & 4761 & 1443 & 30.3 & 1714 & 36.0 & 1604 & 33.7 & & \\
\hline Third tertile $(220 \mathrm{mg})$ & 4761 & 1431 & 30.1 & 1433 & 30.7 & 1897 & 40.6 & & \\
\hline Total fat * (average) & & & & & & & & $<0.001$ & 0.33 \\
\hline First tertile (74 g) & 4761 & 2335 & 49.0 & 1418 & 29.8 & 1008 & 21.2 & & \\
\hline Second tertile (93 g) & 4761 & 1399 & 29.4 & 1815 & 38.1 & 1547 & 31.6 & & \\
\hline Third tertile (112 g) & 4761 & 1027 & 21.6 & 1528 & 32.1 & 2206 & 47.2 & & \\
\hline Saturated fat $*$ (average) & & & & & & & & $<0.001$ & 0.13 \\
\hline First tertile $(22 \mathrm{~g})$ & 4761 & 2107 & 44.3 & 1354 & 28.4 & 1300 & 27.8 & & \\
\hline Second tertile $(30 \mathrm{~g})$ & 4761 & 1315 & 28.1 & 1825 & 39.1 & 1621 & 34.7 & & \\
\hline Third tertile $(41 \mathrm{~g})$ & 4761 & 1339 & 28.7 & 1582 & 33.9 & 1840 & 39.0 & & \\
\hline Urinary sodium (average) & & & & & & & & $<0.001$ & -0.08 \\
\hline First tertile (6 g/day) & 4665 & 1345 & 28.8 & 1537 & 33.0 & 1773 & 38.1 & & \\
\hline Second tertile ( $10 \mathrm{~g} /$ day) & 4667 & 1528 & 32.8 & 1563 & 33.6 & 1576 & 33.9 & & \\
\hline Third tertile (19 g/day) & 4642 & 1782 & 38.4 & 1557 & 33.4 & 1303 & 28.0 & & \\
\hline
\end{tabular}

${ }^{*}$ Energy-adjusted nutrient; ** $p$ value of the chi-square test; *** Pearson correlation coefficient between selenium and other nutrients $(p<0.001)$.

Table 3 shows the inverse association between Se intake and subclinical hypothyroidism based on logistic regression models adjusted for gender, self-reported race, age, per capita income, current smoking, current alcohol use, physical activity, use of supplements, dietary change in the past 6 months, total energy intake, total and saturated fat consumption, zinc and vitamin A consumption, urinary sodium, nutritional status, diabetes, hypertension and dyslipidemia.

Table 3. Logistic regression models between subclinical hypothyroidism (outcome) ${ }^{*}$ and selenium intake adjusted for the consumption of zinc, vitamin A, total and saturated fats and urinary sodium. ELSA-Brasil study, 2017.

\begin{tabular}{|c|c|c|c|c|c|c|c|c|c|c|}
\hline & \multicolumn{2}{|c|}{ Model $1^{\text {a }}$} & \multicolumn{2}{|c|}{ Model $2^{b}$} & \multicolumn{2}{|c|}{ Model $3^{c}$} & \multicolumn{2}{|c|}{ Model $4^{\mathrm{d}}$} & \multicolumn{2}{|c|}{ Model $5^{\mathrm{e}}$} \\
\hline & OR & $95 \%$ CI & OR & $95 \% \mathrm{CI}$ & OR & $95 \%$ CI & OR & $95 \%$ CI & OR & $95 \%$ CI \\
\hline \multicolumn{11}{|l|}{ Selenium ** } \\
\hline First tertile (0-187 mg) & 1 & _ $\quad$ - & 1 & _ $\quad$ - & 1 & - $\quad-$ & 1 & - $\quad$ - & 1 & - $\quad-$ \\
\hline Second tertile (188-232 mg) & 0.89 & 0.741 .08 & 0.85 & 0.711 .03 & 0.81 & 0.670 .98 & 0.80 & 0.660 .97 & 0.79 & 0.650 .96 \\
\hline Third tertile (233-1087 mg) & 0.90 & 0.751 .08 & 0.86 & 0.701 .05 & 0.74 & 0.600 .92 & 0.73 & 0.590 .91 & 0.72 & $0.58 \quad 0.90$ \\
\hline
\end{tabular}




\section{Discussion}

Selenium intake showed an inverse association with subclinical hypothyroidism, independent of the intake of energy and other nutrients that were previously shown to be correlated with thyroid function.

Most studies that analyzed the effects of Se on thyroid function and hypothyroidism are experimental and three studies [36-38] assessed the effect of Se supplementation on the enzymatic and hormonal functions essential for thyroid maintenance in Se-deficient rats. These studies found a positive correlation between Se and the analyzed parameters. Understanding the health implications of Se in humans has been far more difficult, as Se intakes nor tissue levels of free-living people can seldom be ascertained with the levels of confidence typical of controlled animal experiments [17].

It is well known that the thyroid gland retains selenium and selenoprotein activity even under conditions of severe deficiency [39]. However, it remains unknown whether selenium modulates peripheral thyroid hormone action via less prioritized mechanisms [13]. A cross-sectional study [15] involving 6152 participants from two municipalities in China determined the prevalence of thyroid diseases in two similar areas, except in participants with extreme Se levels and showed that low selenium status was associated with increased risk of thyroid disease and concluded that increased selenium intake may reduce the risk in areas of low selenium intake. However, Thomson et al. [40] analyzed data from two cross-sectional and three interventional studies conducted in New Zealand on the effects of Se on thyroid metabolism and found no significant correlations, even after Se supplementation.

Despite data on large controlled trials, that would provide more reliable evidence, are scarce, randomized controlled trials, conducted in healthy and diseased participants and used different doses of supplemental Se, found no significant effects of this micronutrient on the outcome of interest [41-44]. Studies that reported detrimental $[45,46]$ or worsening results also were found in literature [47]. Despite that, in general, an improvement on levels of Se were observed $[45,48,49]$. In a prospective randomized controlled study by Pirola et al. [50] involving 192 patients supplemented with Se for 4 months, euthyroidism was restored in 1/3 of subclinical hypothyroidism patients with autoimmune thyroiditis.

Despite the lack of studies and inconclusive evidence, Negro et al. [51] (2016) evaluated a sample of 778 Italian endocrinologists and observed that more than two-thirds of the study population used Se supplementation as a therapy for subclinical hypothyroidism and $60 \%$ of this sample suggested daily doses of 100-200 $\mu \mathrm{g}, 20-30 \%$ recommended doses of $<100 \mu \mathrm{g}$ and 10-20\% suggested doses of $>200 \mu \mathrm{g}$. These recommendations are higher than those proposed by the Dietary Reference Intakes [52].

The present study has limitations. Our estimates of selenium intake were obtained from a FFQ, a method that is widely used in large epidemiological studies to determine the frequency of consumption of specific food products in 1 year [29]. This method is appropriated to rank individual according to levels of intake, however, it is not considered the most appropriate for the quantitative analysis of micronutrients because it tends to overestimate dietary intake and. Moreover, as it lacks accuracy, does not allow the evaluation of the adequacy of the ingested micronutrients within this period, therefore only allowing a comparison between major and minor consumers. Nutrient intake can be better estimated using repeated 24-h recalls and dietary records because the mean values obtained from several days of dietary intake yield safer and more reliable results [53]. However, as these methods are based on the individual report, they still are susceptible to bias. For greater accuracy of the selenium levels in the participants, it would be necessary to use biomarkers capable of indicating more precisely the condition of these individuals $[3,12,20]$. Especially taking into account that there is enormous variability of Se levels in foods, as it is dependent exclusively on the soil properties from which they were harvested. So, the demonstrated selenium consumption tertiles may not correspond to the participants' exact selenium levels. However, we used the obtained Se estimates to rank individual according to their intake and we used the distribution of this intake in our population to define cutoffs. We used the same composition table that was used in the last National Dietary Survey 2009-2009 in Brazil, carefully checked for the completeness of Se information. In this case, we expect a systematic 
bias and a hypothesized relationship is possible to identify, that need to be confirmed. Another important limitation lies in the design of the study, since it is a cross-sectional observational study and suffer from limitations inherent to the observational design, including exposure misclassification and unmeasured confounding. Although it has been adjusted by several dietary and non-dietary factors, these are data from ELSA-Brasil baseline and we did not longitudinally evaluate food consumption in this population, which would be more appropriate. Therefore, because it is an observational study, the results found on the relationship between selenium and the outcome cannot be interpreted as a causal relation, requiring that they would be confirmed in further studies.

\section{Conclusions}

The results revealed an inverse correlation between Se intake and subclinical hypothyroidism. However, further research is needed to confirm the involvement of Se in subclinical hypothyroidism using more accurate methodologies of dietary assessment and nutritional status to evaluate this relationship.

Author Contributions: Designed the study's analytic strategy: G.R.G.A., B.G., I.M.B., D.M.M. Analyzed the data: G.R.G.A., B.G., D.M.M. Wrote the article: G.R.G.A. Discussion and final review: G.R.G.A., B.G., D.M.M., P.A.L., I.M.B. All authors participated in critically revising the manuscript and approved the final version.

Funding: The ELSA-Brasil baseline study was supported by the Brazilian Ministry of Health (Science and Technology Department) and the Brazilian Ministry of Science and Technology and National Research Council (grants 01060010.00 RS, 01060212.00 BA, 01060300.00 ES, 01060278.00 MG, 01060115.00 SP and 0106 0071.00 RJ). The research center of São Paulo was also supported by São Paulo Research Foundation (FAPESP; grant 2011/12256-4). G.R.G.A received a scholarship from the FAPESP (grant 2016/22077-3). No funding agencies had a role in the study design, data collection, analysis, decision to publish, or preparation of the article.

Acknowledgments: Not applicable.

Conflicts of Interest: The authors declare no conflict of interest.

\section{References}

1. Ichiki, T. Thyroid hormone and vascular remodeling. J. Atheroscler. Thromb. 2016, 23, 266-275. [CrossRef] [PubMed]

2. Bensenor, I.M.; Olmos, R.D.; Lotufo, P.A. Hypothyroidism in the elderly: Diagnosis and management. Clin. Interv. Aging 2012, 7, 97-111. [CrossRef] [PubMed]

3. Vinceti, M.; Filippini, T.; Del Giovane, C.; Dennert, G.; Zwahlen, M.; Brinkman, M.; Zeegers, M.P.; Horneber, M.; D'Amico, R.; Crespi, C.M. Selenium for preventing cancer. Cochrane Database Syst. Rev. 2018, 1, CD005195. [CrossRef] [PubMed]

4. Fatourechi, V. Subclinical hypothyroidism: An update for primary care physicians. Mayo Clin. Proc. 2009, 84, 65-71. [CrossRef] [PubMed]

5. Bensenor, I.M.; Goulart, A.C.; Lotufo, P.A.; Menezes, P.R.; Scazufca, M. Prevalence of thyroid disorders among older people: Results from the São Paulo Ageing and Health Study. Cad. Saúde Pública 2011, 27, 155-161. [CrossRef] [PubMed]

6. Olmos, R.D.; Figueiredo, R.C.; Aquino, E.M.; Lotufo, P.A.; Bensenor, I.M. Gender, race and socioeconomic influence on diagnosis and treatment of thyroid disorders in the Brazilian Longitudinal Study of Adult Health (ELSA-Brasil). Braz. J. Med. Biol. Res. 2015, 48, 751-758. [CrossRef] [PubMed]

7. Sichieri, R.; Baima, J.; Marante, T.; de Vasconcellos, M.T.; Moura, A.S.; Vaisman, M. Low prevalence of hypothyroidism among black and Mulatto people in a population-based study of Brazilian women. Clin. Endocrinol. 2007, 66, 803-807. [CrossRef] [PubMed]

8. Ventura, M.; Melo, M.; Carrilho, F. Selenium and thyroid disease: From pathophysiology to treatment. Int. J. Endocrinol. 2017, 2017, 1297658. [CrossRef] [PubMed]

9. Schomburg, L. Selenium, selenoproteins and the thyroid gland: Interactions in health and disease. Nat. Rev. Endocrinol. 2011, 8, 160-171. [CrossRef] [PubMed]

10. O'Kane, S.M.; Mulhern, M.S.; Pourshahidi, L.K.; Strain, J.J.; Yeates, A.J. Micronutrients, iodine status and concentrations of thyroid hormones: A systematic review. Nutr. Rev. 2018, 76, 418-431. [CrossRef] [PubMed] 
11. Behne, D.; Hilmert, H.; Scheid, S.; Gessner, H.; Elger, W. Evidence for specific selenium target tissues and new biologically important selenoproteins. Biochim. Biophys. Acta 1988, 966, 12-21. [CrossRef]

12. Fairweather-Tait, S.J.; Bao, Y.; Broadley, M.R.; Collings, R.; Ford, D.; Hesketh, J.E.; Hurst, R. Selenium in human health and disease. Antioxid. Redox Signal. 2011, 14, 1337-1383. [CrossRef] [PubMed]

13. Schomburg, L.; Riese, C.; Michaelis, M.; Griebert, E.; Klein, M.O.; Sapin, R.; Schweizer, U.; Köhrle, J. Synthesis and metabolism of thyroid hormones is preferentially maintained in selenium-deficient transgenic mice. Endocrinology 2006, 147, 1306-1313. [CrossRef] [PubMed]

14. Parshukova, O.; Potolitsyna, N.; Shadrina, V.; Chernykh, A.; Bojko, E. Features of selenium metabolism in humans living under the conditions of North European Russia. Int. Arch. Occup. Environ. Health 2014, 87, 607-614. [CrossRef] [PubMed]

15. Wu, Q.; Rayman, M.P.; Lv, H.; Schomburg, L.; Gao, C.; Chen, P.; Zhuang, G.; Zhang, Z.; Peng, X.; Li, H.; et al. Low population selenium status is associated with increased prevalence of thyroid disease. J. Clin. Endocrinol. Metab. 2015, 100, 4037-4047. [CrossRef] [PubMed]

16. Oldfield, J.E. Selenium World Atlas; Selenium-Tellurium Development Association: Grimbergen, Belgium, 2002.

17. Combs, G.F. Selenium in global food systems. Br. J. Nutr. 2001, 85, 517-547. [CrossRef] [PubMed]

18. Donadio, J.L.; Guerra-Shinohara, E.M.; Rogero, M.M.; Cozzolino, S.M. Influence of Gender and SNPs in GPX1 Gene on Biomarkers of Selenium Status in Healthy Brazilians. Nutrients 2016, 8, 81. [CrossRef] [PubMed]

19. Favaro, D.I.; Hui, M.L.; Cozzolino, S.M.; Maihara, V.A.; Armelin, M.J.; Vasconcellos, M.B.; Yuyama, L.K.; Boaventura, G.T.; Tramonte, V.L. Determination of various nutrients and toxic elements in different brazilian regional diets by neutron activation analysis. J. Trace Elem. Med. Biol. 1997, 11, 129-136. [CrossRef]

20. Combs, G.F. Biomarkers of selenium status. Nutrients 2015, 7, 2209-2236. [CrossRef] [PubMed]

21. Ferreira, K.S.; Gomes, J.C.; Bellato, C.R.; Jordão, C.P. Concentrações de selênio em alimentos consumidos no Brasil. Rev. Panam. Salud Publica 2002, 11, 172-177. [CrossRef] [PubMed]

22. Kvicala, J.; Zamrazil, V. Effect of iodine and selenium upon thyroid function. Cent. Eur. J. Public Health 2003, 11, 107-113. [PubMed]

23. Combs, G.F.; Midthune, D.N.; Patterson, K.Y.; Canfield, W.K.; Hill, A.D.; Levander, O.A.; Taylor, P.R.; Moler, J.E.; Patterson, B.H. Effects of selenomethionine supplementation on selenium status and thyroid hormone concentrations in healthy adults. Am. J. Clin. Nutr. 2009, 89, 1808-1814. [CrossRef] [PubMed]

24. Thomson, C.D.; Campbell, J.M.; Miller, J.; Skeaff, S.A.; Livingstone, V. Selenium and iodine supplementation: Effect on thyroid function of older New Zealanders. Am. J. Clin. Nutr. 2009, 90, 1038-1046. [CrossRef] [PubMed]

25. Moreno-Reyes, R.; Mathieu, F.; Boelaert, M.; Begaux, F.; Suetens, C.; Rivera, M.T.; Nève, J.; Perlmutter, N.; Vanderpas, J. Selenium and iodine supplementation of rural Tibetan children affected by Kashin-Beck osteoarthropathy. Am. J. Clin. Nutr. 2003, 78, 137-144. [CrossRef] [PubMed]

26. Angstwurm, M.W.; Schopohl, J.; Gaertner, R. Selenium substitution has no direct effect on thyroid hormone metabolism in critically ill patients. Eur. J. Endocrinol. 2004, 151, 47-54. [CrossRef] [PubMed]

27. Aquino, E.M.L.; Vasconcellos-Silva, P.R.; Coeli, C.M.; Araújo, M.J.; Santos, S.M.; De Figueiredo, R.C.; Duncan, B.B. Aspectos éticos em estudos longitudinais: O caso do ELSA-Brasil. Rev. Saúde Pública 2013, 47, 19-26. [CrossRef] [PubMed]

28. Bensenor, I.M.; Griep, R.H.; Pinto, K.A.; de Faria, C.P.; Felisbino-Mendes, M.; Caetano, E.I.; Albuquerque, L.S.; Schmidt, M.I. Rotinas de organização de exames e entrevistas no centro de investigação ELSA-Brasil. Rev. Saúde Pública 2013, 47, 37-47. [CrossRef] [PubMed]

29. Chor, D.; Alves, M.G.M.; Giatti, L.; Cade, N.V.; Nunes, M.A.; Molina, M.C.B.; Bensenor, I.M.; Aquino, E.M.L.; Passos, V.; Santos, S.M.; et al. Questionário do ELSA-Brasil: Desafios na elaboração de instrumento multidimensional. Rev. Saúde Pública 2013, 47, 27-36. [CrossRef] [PubMed]

30. Molina, M.C.B.; Bensenor, I.M.; Cardoso, L.O.; Velazquez-Melendez, G.; Drehmer, M.; Pereira, T.S.S.; Faria, C.P.; Melere, C.; Manato, L.; Gomes, A.L.C.; et al. Reprodutibilidade e validade relativa do Questionário de Frequência Alimentar do ELSA-Brasil. Cad. Saúde Pública 2013, 29, 379-389. [CrossRef] 
31. Fedeli, L.G.; Vidigal, P.G.; Leite, C.M.; Castilhos, C.D.; Pimentel, R.A.; Maniero, V.C.; Mill, J.G.; Lotufo, P.A.; Pereira, A.C.; Bensenor, I.M. Logistics of collection and transportation of biological samples and the organization of the centrallaboratory in the ELSA-Brasil. Rev. Saude Publica 2013, 47, 63-71. [CrossRef] [PubMed]

32. Willet, W. Nutritional Epidemiology; Oxford University Press: New York, NY, USA, 2013.

33. World Health Organization. Obesity: Preventing and Managing the Global Epidemic. Report of a WHO Consultation; WHO Technical Report Series 894; World Health Organization: Geneva, Switzerland, 2000; Available online: http:/ / www.who.int/iris/handle/10665/42330 (accessed on 10 April 2018).

34. Mezzomo, T.R.; Nadal, J. Efeito dos nutrientes e substâncias alimentares na função tireoidiana e no hipotireoidismo. Demetra 2016, 11, 427-443. [CrossRef]

35. McLean, R.M. Measuring population sodium intake: A review of methods. Nutrients 2014, 6, 4651-4662. [CrossRef] [PubMed]

36. Chanoine, J.P.; Safran, M.; Farwell, A.P.; Tranter, P.; Ekenbarger, D.M.; Dubord, S.; Alex, S.; Arthur, J.R.; Beckett, G.J.; Braverman, L.E.; et al. Selenium deficiency and type II $5^{\prime}$-deiodinase regulation in the euthyroid and hypothyroid rat: Evidence of a direct effect of thyroxine. Endocrinology 1992, 131, 479-484. [CrossRef] [PubMed]

37. Kralik, A.; Eder, K.; Kirchgessner, M. Influence of zinc and selenium deficiency on parameters relating to thyroid hormone metabolism. Horm. Metab. Res. 1996, 28, 223-226. [CrossRef] [PubMed]

38. Beckett, G.J.; MacDougall, D.A.; Nicol, F.; Arthur, J.R. Inhibition of type I and type II iodothyronine deiodinase activity in rat liver, kidney and brain produced by selenium deficiency. Biochem. J. 1989, 259, 887-892. [CrossRef] [PubMed]

39. Köhrle, J.; Jakob, F.; Contempre, B.; Dumont, J.E. Selenium, the thyroid and the endocrine system. Endocr. Rev. 2005, 26, 944-984. [CrossRef] [PubMed]

40. Thomson, C.D.; McLachlan, S.K.; Grant, A.M.; Peterson, E.; Lillico, A.J. The effect of selenium on thyroid status in a population with marginal selenium and iodine status. Br. J. Nutr. 2005, 94, 962-968. [CrossRef] [PubMed]

41. Jacobs, J.; Kahana, M.J. Neural representations of individual stimuli in humans revealed by gamma-band ECoG activity. J. Neurosci. 2009, 29, 10203-10214. [CrossRef] [PubMed]

42. Van Zuuren, E.J.; Albusta, A.Y.; Fedorowicz, Z.; Carter, B.; Pijl, H. Selenium supplementation for Hashimoto's thyroiditis. Cochrane Database Syst. Rev. 2013. [CrossRef] [PubMed]

43. Eskes, S.A.; Endert, E.; Fliers, E.; Birnie, E.; Hollenbach, B.; Schomburg, L.; Köhrle, J.; Wiersinga, W.M. Selenite supplementation in euthyroid subjects with thyroid peroxidase antibodies. Clin. Endocrinol. 2014, 80, 444-451. [CrossRef] [PubMed]

44. Kahaly, G.J.; Riedl, M.; König, J.; Diana, T.; Schomburg, L. Double-Blind, Placebo-Controlled, Randomized Trial of Selenium in Graves Hyperthyroidism. J. Clin. Endocrinol. Metab. 2017, 102, 4333-4341. [CrossRef] [PubMed]

45. Winther, K.H.; Bonnema, S.J.; Cold, F.; Debrabant, B.; Nybo, M.; Cold, S.; Hegedus, L. Does selenium supplementation affect thyroid function? Results from a randomized, controlled, double-blinded trial in a Danish population. Eur. J. Endocrinol. 2015, 172, 657-667. [CrossRef] [PubMed]

46. Mao, J.; Pop, V.J.; Bath, S.C.; Vader, H.L.; Redman, C.W.; Rayman, M.P. Effect of low-dose selenium on thyroid autoimmunity and thyroid function in UK pregnant women with mild-to-moderate iodine deficiency. Eur. J. Nutr. 2016, 55, 55-61. [CrossRef] [PubMed]

47. Contempre, B.; Dumont, J.E.; Ngo, B.; Thilly, C.H.; Diplock, A.T.; Vanderpas, J. Effect of selenium supplementation in hypothyroid subjects of an iodine and selenium deficient area: The possible danger of indiscriminate supplementation of iodine-deficient subjects with selenium. J. Clin. Endocrinol. Metab. 1991, 73, 213-215. [CrossRef] [PubMed]

48. Rayman, M.P.; Thompson, A.J.; Bekaert, B.; Catterick, J.; Galassino, R.; Hall, E.; Warren-Perry, M.; Beckett, G.J. Randomized controlled trial of the effect of selenium supplementation on thyroid function in the elderly in the United Kingdom. Am. J. Clin. Nutr. 2008, 87, 370-378. [CrossRef] [PubMed]

49. Hawkes, W.C.; Keim, N.L.; Diane Richter, B.; Gustafson, M.B.; Gale, B.; Mackey, B.R.; Bonnel, E.L. High-selenium yeast supplementation in free-living North American men: No effect on thyroid hormone metabolism or body composition. J. Trace Elem. Med. Biol. 2008, 22, 131-142. [CrossRef] [PubMed] 
50. Pirola, I.; Gandossi, E.; Agosti, B.; Delbarba, A.; Cappelli, C. Selenium supplementation could restore euthyroidism in subclinical hypothyroid patients with autoimmune thyroiditis. Endokrynol. Pol. 2016, 67, 567-571. [CrossRef] [PubMed]

51. Negro, R.; Attanasio, R.; Grimaldi, F.; Morcocci, C.; Guglielmi, R.; Papine, E. A 2016 Italian survey about the clinical use of selenium in thyroid disease. Eur. Thyroid J. 2016, 5, 164-170. [CrossRef] [PubMed]

52. Institute of Medicine. Dietary Reference Intakes for Vitamin C, Vitamin E, Selenium and Carotenoids; National Academy Press: Washington, DC, USA, 2000; Available online: http:/ /books.nap.edu/catalog/9810.html (accessed on 16 April 2018).

53. Thompson, F.E.; Kirkpatrick, S.I.; Subar, A.F.; Reedy, J.; Schap, T.E.; Wilson, M.M.; Krebs-Smith, S.M. The national cancer institute's dietary assessment primer: A resource for diet research. J. Acad. Nutr. Diet. 2015, 115, 1986-1995. [CrossRef] [PubMed]

(C) 2018 by the authors. Licensee MDPI, Basel, Switzerland. This article is an open access article distributed under the terms and conditions of the Creative Commons Attribution (CC BY) license (http://creativecommons.org/licenses/by/4.0/). 